\title{
Improving the design of super-lift Luo converter using hybrid switching capacitor-inductor cell for PV system
}

\author{
Hussein Abdul-Khuder Hussein, Hassan Jassim Motlak \\ Department of Electrical Engineering, Babylon University, City of hilla, Iraq
}

\section{Article Info}

Article history:

Received Sep 18, 2021

Revised Dec 19, 2021

Accepted Dec 29, 2021

Keywords:

DC-DC converter

High gain converter

Maximum power point tracker

Positive output converter

PV system

ABSTRACT

In this article, an improvement to the positive output super-lift Luo converter (POSLC) has been proposed to get high gain at a low duty cycle. Also, reduce the stress on the switch and diodes, reduce the current through the inductors to reduce loss, and increase efficiency. Using a hybrid switch unit composed of four inductors and two capacitors it is replaced by the main inductor in the elementary circuit. It's charged in parallel with the same input voltage and discharged in series. The output voltage is increased according to the number of components. The gain equation is modeled. The boundary condition between continuous conduction mode (CCM) and discontinuous conduction mode (DCM) has been derived. Passive components are designed to get high output voltage ( 8 times at $\mathrm{D}=0.5$ ) and low ripple about (0.004). The circuit is simulated and analyzed using MATLAB/Simulink. Maximum power point tracker (MPPT) controls the converter to provide the most interest from solar energy.
\end{abstract}

This is an open access article under the CC BY-SA license.

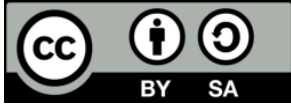

\section{Corresponding Author:}

Hussein Abdul-Khuder Hussein

Department of Electrical Engineering

Babylon University, City of hilla, Babil Province, Iraq

Email: hussein.radi@student.uobabylon.edu.iq

\section{INTRODUCTION}

Direct current (DC-DC) converters are essential to meet residential, commercial, agricultural and industrial needs in our daily lives [1]. Modern power systems require compact, robust, powerful, and inexpensive equipment. The linear controller is best replaced by a DC-DC converter. Many modern DC-DC converter systems have been patented through extensive research [2]-[4]. These DC-DC converters can be used in a variety of applications, including hybrid vehicles, solar cell applications, and more while the circuits are implemented in traction, machine motors, and fuel cells [5]-[7]. The super lift (SL) method and voltage lift (VL) to improve the converter to increase the voltage without ripple [8]. These techniques are used to design converters, gradually improving (VL) technology or (SL) technology to increase the output voltage geometrically [9]. The multi-timed-multi level DC-DC converter technique was used to lift the voltage with reduce the stress on the switches, the three levels converter was three times higher than that of the conventional boost converter [10], [11].

Many modifications have been proposed to (POSLC) used the switching cell to boost the voltage [12]. The modification proposed to obtain four times the gain at half-duty cycle is to add an inductor and diode in series and connect with the primary diode in parallel (POSLC) [12], to reach a higher voltage gain. Another modification by adding four capacitors and four diodes can raise the output voltage about five times at one-half duty cycle [13], recently a modification on (POSLC) has been proposed [14] using a hybrid switching cell combined from two inductors, one capacitor and two diodes, the voltage gain produced from this modification is the same as [15]. 
The primary Luo converter cannot provide such a high conversion gain (at least 10 times the gain is required in the application), and the solution is to use a switched capacitor-inductor unit [16]. In order to obtain non-isolated control, they are integrated into a simple converter. An electronic circuit that can increase the voltage ten times or more and operate with high efficiency. This concept has been explored in various journals and there are several solutions [17], [18]. A lot of high gain DC-DC converter has been proposed in general structure [18] we focused on the Luo converter because it has proven its efficiency, practicality and for its extensive and comprehensive analysis. In this paper a new modification on super-lift Luo converter has been proposed, capacitor-inductor switching cell composed of four inductors and two capacitors has been used to achieve higher voltage gain than elementary converter since the output voltage is 8 times the input voltage at $\mathrm{D}=0.5$ and 20 times the input voltage at $\mathrm{D}=0.8$.

\section{RESEARCH METHOD}

Maximum power point tracking (MPPT) was used in the system as shown in Figure 1, to meet full power delivery to the load and high output boost voltage to satisfy maximum interest from the photovoltaic (PV) system. PV generation system is becoming important as it offers many advantages including no fuel costs, almost no pollution, little maintenance, and no noise emission [19]. To implement an off-grid PV system for use in remote areas, so we propose in this paper the positive output super lift Luo converter with hybrid capacitor-inductor switching cell, which has high efficiency, very low equivalent resistance, high output voltage, decrease the inductors current, and low output voltage ripple. can operate with gain more than four times of input voltage at a very low duty cycle when control with MPPT.

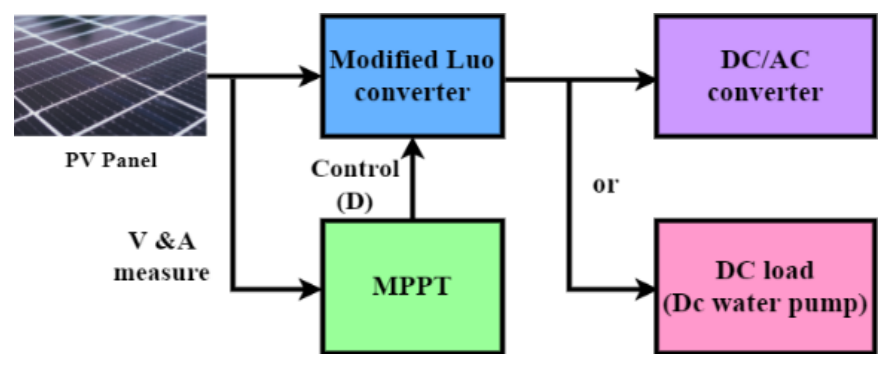

Figure 1. The complete system proposed Luo converter

\subsection{Topology of PV model}

A photovoltaic device converts solar energy into electrical energy using one or more solar panels, Photovoltaic panels are made up mostly of solar cells. The solar cells are connected in parallel or series, depending on the voltage and current needs, respectively. The voltage of the panel is improved by connecting the solar cells in series, while the current value of the panel is improved by arranging the cells in parallel [20], Figure 2 shows a circuit diagram of the PV model.

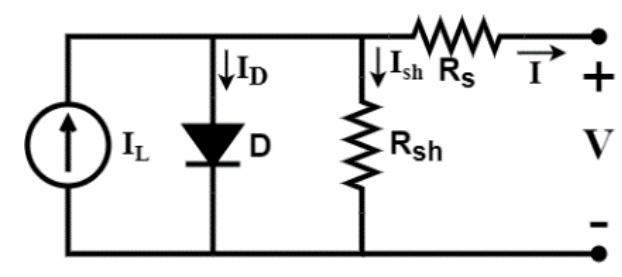

Figure 2. PV model circuit [21]

The PV system's P-V and I-V properties are not linear. Temperature and irradiation intensity are the two major factors that influence the performance of a PV device. The voltage and current provided by the PV device change as the temperature and irradiation level change. The solar module's nominal working conditions are $25^{\circ} \mathrm{C}$ temperature, $1000 \mathrm{~W} / \mathrm{m} 2(\mathrm{G}=1)$ irradiation, Figure 3 depicts the $\mathrm{P}-\mathrm{V}$ and $\mathrm{I}-\mathrm{V}$ properties of a PV cell [22]. The open-circuit voltage (VOC) is the highest voltage a cell will produce when I=zero and 
the short-circuit current (ISC) is the current that belong to a short circuit when V=zero. The PV cell produces maximum power at just one point during service, which is known as the maximum power point (MPP). The maximum current, maximum voltage, and maximum power of the solar cell are represented in the graph by I'm, Vm, and Pm, respectively. The mathematical expression for the output current of an ideal cell [23], [24] is $(1)$,

$$
I=I_{P V}-I_{d}
$$

$I_{d}$ is the Shockley equation, $R_{s h}$ is the shunt resistance of the model, and $I_{p v}$ is the current generated by light, which is proportional to solar irradiation. The solar cell's light produced current is primarily determined by solar irradiation and its work temperature, which is measured in Celsius.

$$
I_{P V}=\left[I_{S C}+K_{I}\left(T_{c}-T_{R}\right)\right] \cdot G
$$

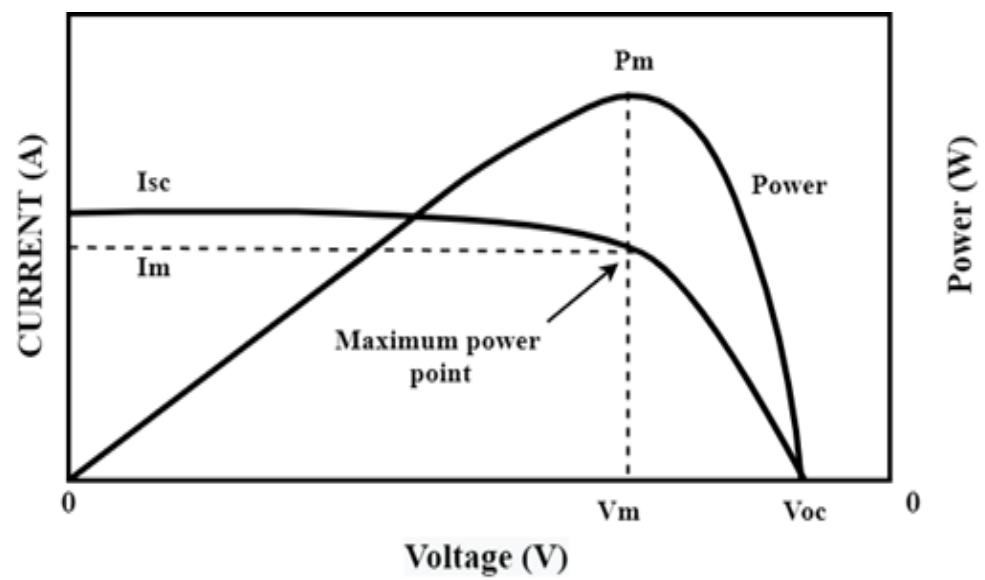

Figure 3. I-V and P-V characteristics of solar cell [25]

ISC is the cells short-circuit current at $\left(25^{\circ} \mathrm{C}\right)$ and $(\mathrm{G}=1)$, KI is the cell's short-circuit current temperature co-efficient, $\mathrm{Tr}$ and $\mathrm{Tc}$ are the cell's reference and working temperatures respectively. The Shockley equation is,

$$
\begin{aligned}
& I_{d}=I_{S}\left\{\exp \left(\frac{q}{A K T c}\right)-1\right\} \\
& I=I_{P V}-I_{d}-I_{P} \\
& I=I_{P V}-I_{S}\left\{\exp \left(\frac{q}{A K T c}\right)-1\right\}-\frac{V+I R_{S e}}{R_{P}}
\end{aligned}
$$

to achieve the required output power, the solar cells must be connected in a series-parallel configuration. The generalized PV array mathematical equation with (Ns) number of modules connected in sequence and (Np) number of modules connected in parallel, $q$ is the electron charge $\left[1.60 \times 10^{-19} \mathrm{C}\right], k$ is the Boltzmann constant $\left[1.38 \times 10^{-23} \mathrm{~J} / \mathrm{K}\right]$, is,

$$
\begin{aligned}
& I=I_{P V} N_{P}-I_{S} N_{P}\left\{\exp \left(\frac{q V}{A K T c N S}+\frac{I R_{S e}}{N_{P}}\right)-1\right\} \\
& I_{S}=I_{r s}\left(\frac{T_{c}}{T_{r}}\right)^{3} \exp \left[\frac{q E_{g}}{A_{k}}\left(\frac{1}{T_{c}}-\frac{1}{T_{r}}\right)\right]
\end{aligned}
$$

where (Eg) is the bandgap energy of the semiconductor and (Irs) is the reverse saturation current of a cell at a reference temperature and sun irradiation. For polycrystalline $\mathrm{Si},(\mathrm{Eg})$ is around $1.12 \mathrm{eV}$ at $25^{\circ} \mathrm{C}$ [24], [26]. The (8) can be used to calculate a cell's reverse saturation current (Irs). 


$$
I_{R S}=\frac{I_{S C}}{\exp \left(\frac{q}{A K T_{C}(n)^{N_{S}}} V o\right)-1}
$$

PV systems employ DC-DC step-up converters to control the voltage generated by PV modules and to raise the module voltage. One switch $(\mathrm{S})$, one inductor $(\mathrm{L})$, capacitors $(\mathrm{C} 1$ and $\mathrm{C} 2)$, and two diodes make up the (POSLC). Figure 4 depicts the (POSLC) circuit architecture [27], as well as its modeling (9) (on-state) and (10) (off-state) for displaying the output voltage gain [28].

$$
\begin{aligned}
& V i n=V L=V c 1=L \Delta i / d t \\
& \Delta i=V L(1-D) T / L=V o-2 \operatorname{Vin}(1-D) T / L \\
& G=\frac{V o}{V i n}=\frac{2-D}{1-D}
\end{aligned}
$$

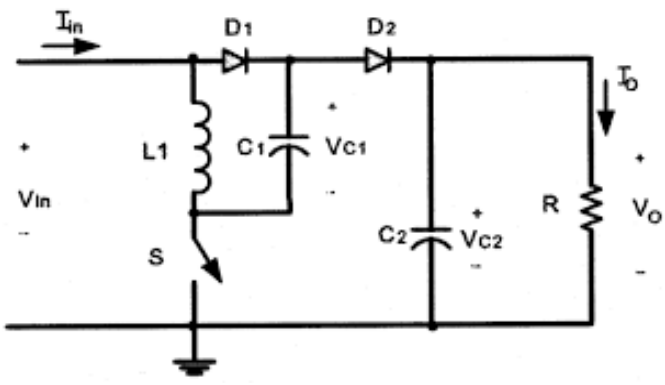

Figure 4. Elementary circuit (POSLC) [29]

\subsection{Modify (POSLC)}

The elementary circuit of (POSLC) is high output voltage gain [30]. We can get many times the input voltage without the need to raise the duty cycle at a level that makes the MOSFET switch cause more losses. Hybrid switching-capacitor-inductor (S-C-L) cell proposed as shown in Figure 5(a) composed of four inductors and two capacitors to raise the voltage about eight times at duty cycle 0.5 . The inductors and the capacitors charge in parallel the same input voltage and discharge in series to increase the output voltage. The modified circuit is shown in Figure 5(a), its on-off state Figures 5(b), and 5(c) consist of four inductors (L1, L2, L3, and L4), three capacitors C1, C2, and C3, output capacitor Co to reduce the output voltage ripple and two diodes Dm1, Dm2 the diode Dm2 protects the circuit from reverse currents. The equation of the converter at switch-on is,

$$
\text { Vin }=V_{L 1}=V_{L 2}=V_{L 3}=V_{L 4}=V_{C 1}=V_{C 2}=V_{C 3}
$$

the voltage of the inductor at switch-off is,

$$
V_{L 1}=\frac{4 V_{i n}-V_{O}}{4}
$$

from the volt-second balance,

$$
V L D T+V L(1-D) T=0
$$

sub (12) and (13) in (14) we get the voltage gain,

$$
G=\frac{V o}{V i n}=\frac{4}{1-D}
$$

in (15) is the output voltage gain equation that means when the duty is 0.5 the output voltage increases eight times. Figure 5(d) shows the relationship between duty cycle and gain for both elementary and modified circuits. 


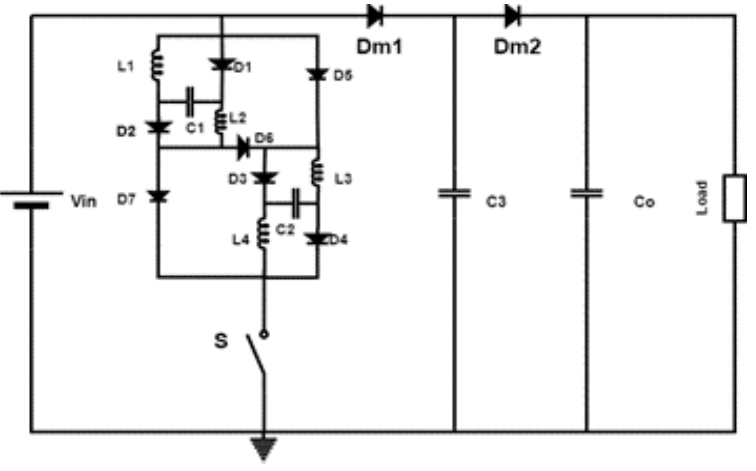

(a)

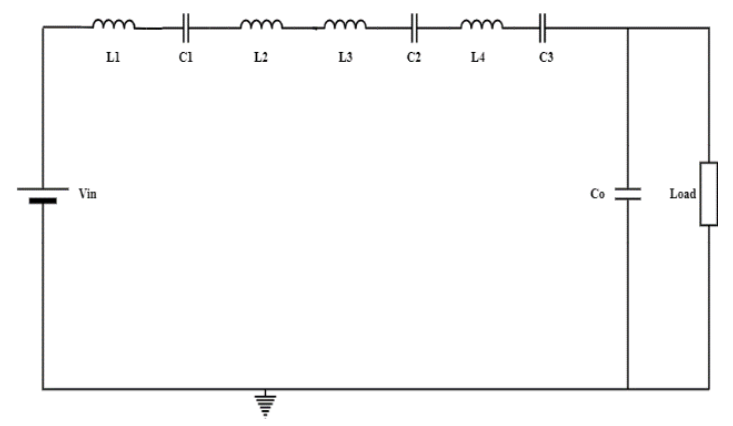

(c)

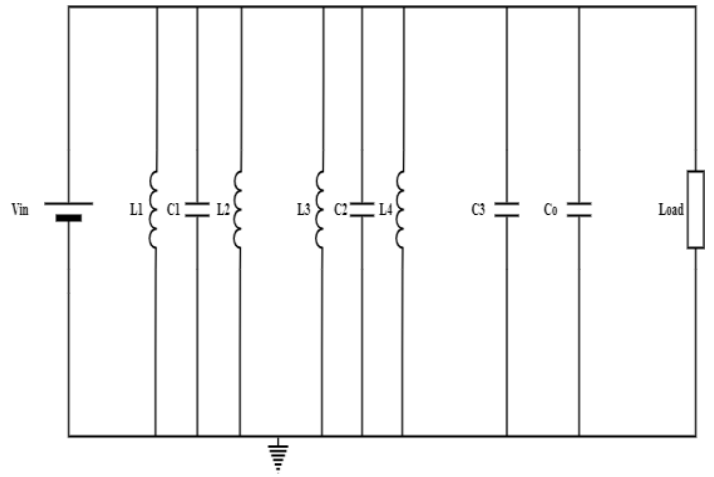

(b)

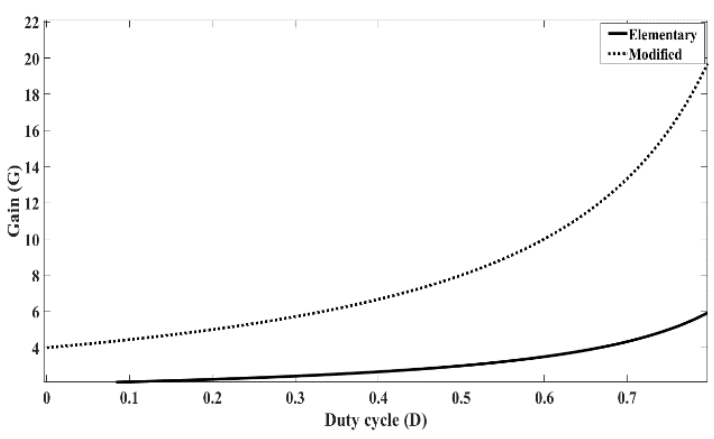

(d)

Figure 5. The modified circuit of (POSLC) is (a) Main circuit, (b) Circuit at switch-on, (c) Circuit at switchoff, and (d) Relationship between gain and duty cycle for both POSLC and MPOSLC

\subsection{Design of passive elements}

From (9),

$$
L_{\text {min }}=\frac{V_{i n} D}{f \Delta I}
$$

- $\Delta I$ : Ripple of inductor current recommended (0.2 to 0.4$)$

- Lmin $=3 \mathrm{e}-4 \mathrm{H}$ It's the minimum value of the inductor to work in continuous-conduction mode (CCM) The output capacitor can be selected from the (17),

$$
C_{o}=\frac{D}{2 f R \Delta v c_{0}}
$$

therefore, the voltage ripple in the capacitors,

$$
\begin{aligned}
& \Delta V C_{1,2,3}=\frac{\Delta \mathbb{Q}}{C_{1,2,3}}=\frac{I o(1-D) T}{C_{1,2,3}}=\frac{1-D}{f C_{1,2,3}} \frac{V o}{R} \\
& \Delta V C_{1,2,3}=\frac{\Delta v_{0} / 2}{v_{0}}=\frac{1-D}{2 f R C_{1,2,3}} \\
& C_{1,2,3 \text { min }}=\frac{1-D}{2 f R \Delta V C_{1,2,3}}
\end{aligned}
$$

$\triangle V C_{o}$ Recommended to set less than $5 \%$ [31].

$C_{\min }=1.5 \mu \mathrm{f} \mathrm{It}$ 's the minimum value of the output capacitor for working in CCM.

Table 1 Shows all the parameters of the modified converter which simulated in MATLAB and shown in Figure 6 with its control unit and PV cell. The proposed Luo converter has been implemented and simulated in MATLAB, with hybrid capacitor-inductor switching cell and perturbation and observation (P\&O) MPPT control, as shown in Figure 6. 
Table 1. Parameters of the proposed converter

\begin{tabular}{lcccc}
\hline I & Parameter & Symbol & Value & Unit \\
\hline 1 & Input voltage & $\mathrm{V}$ & 12 & Volt \\
2 & Output voltage & $\mathrm{V}$ & 96 & Volt \\
3 & Inductors & $\mathrm{L} 1, \mathrm{~L} 2, \mathrm{~L} 3, \mathrm{~L} 4$ & $0.8 \mathrm{~m}$ & henry \\
4 & Capacitors & $\mathrm{C} 1, \mathrm{C} 2, \mathrm{C} 3, \mathrm{Co}$ & $220 \mathrm{u}$ & Farad \\
5 & Switching frequency & $\mathrm{F}$ & 60000 & $\mathrm{HZ}$ \\
6 & Duty cycle & $\mathrm{D}$ & 0.5 & - \\
7 & Load resistance & $\mathrm{R}$ & 50 & Ohm \\
8 & Maximum PV power & $\mathrm{P}$ & 213 & $\mathrm{~W}$ \\
\hline
\end{tabular}
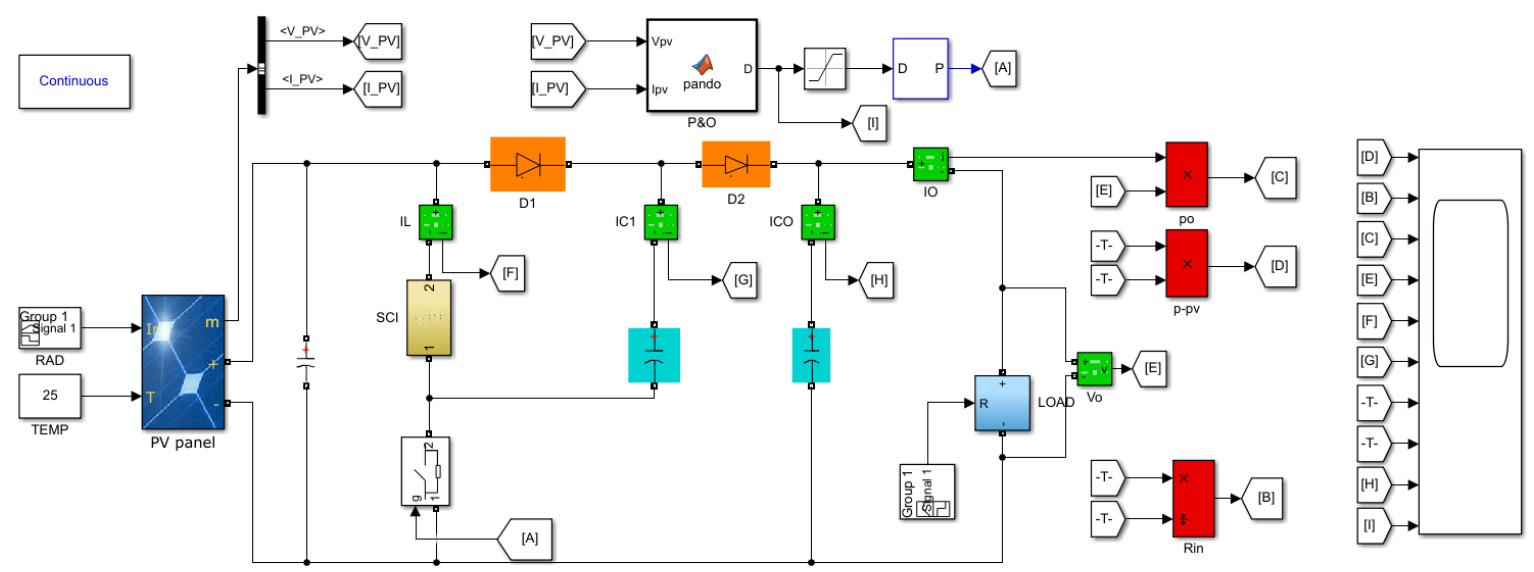

Figure 6. Modified (POSLC) with switching S-C-L cell and MPPT controller

\subsection{Boundary conditions between $\mathrm{CCM}$ and DCM}

When switch (s) on at $\mathrm{T}=0 \sim \mathrm{D}(9)$ satisfied, when switch (s) off at $\mathrm{T}=1-\mathrm{D}$,

$$
\begin{aligned}
& V L=\frac{4 V i n-V o}{4}=L \frac{\Delta_{i}}{(1-D) T} \\
& \Delta_{i}=\frac{(4 V i n-V 0)(1-D) T}{4 L}
\end{aligned}
$$

sub (9) in (22) we get,

$$
(1-D)=\frac{4 \operatorname{Vin} D}{(4 \operatorname{Vin}-V o)}
$$

in (23) showing the duration of time at the switch-off.

$$
I_{L}=\frac{1}{2}(1-D) \Delta i_{L}
$$

$\mathrm{I}_{\mathrm{L}}$ equation from the signal in current waveform, at steady state $I_{c o}=0$ so,

$$
\begin{aligned}
& \frac{1}{2}(1-D) \Delta i_{L}=I_{o} \\
& \frac{1}{2} \frac{4 \operatorname{Vin} D}{(4 \operatorname{Vin}-V o)} * \frac{\operatorname{Vin} D T}{L}=\frac{V o}{R} \\
& \frac{1}{2} * \frac{4 V_{\text {in }}^{2} D^{2}}{(4 \operatorname{Vin}-V o)}=\frac{\operatorname{Vof} L}{R} \\
& \frac{1}{2} * \frac{4 V_{\text {in }}^{2} D^{2}}{(4 \operatorname{Vin}-V o)}=\operatorname{Vo} \tau \\
& V_{o}^{2} \tau-4 V_{o} V_{\text {in }} \tau+2 V_{\text {in }}^{2} D^{2}=0
\end{aligned}
$$


the equation solved by law.

$$
\begin{aligned}
& V_{o}=2 \operatorname{Vin} \mp \sqrt{4 V_{i n}^{2}-\frac{2 V_{i n}^{2} D^{2}}{\tau}} \\
& \tau=\frac{2 D^{2}}{\left(\frac{2+2 D}{1-D}\right)^{2}-4}
\end{aligned}
$$

The (31) draws the boundary condition between CCM and discontinuous conduction mode (DCM) we can draw the curve between duty cycle and $\tau=(\mathrm{f} L) / \mathrm{R}$ as shown in Figure 7 . Notice if we increase the load resistance over its limits the circuits work at DCM that mean the inductor current during the off-state will be zero for a while.

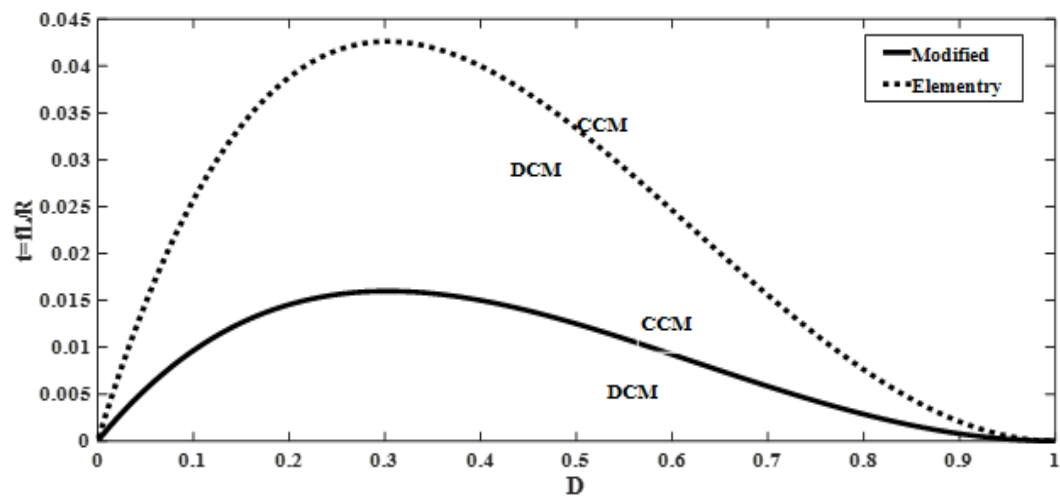

Figure 7. Boundary condition between CCM and DCM for POSLC and MPOSLC

\section{SIMULATION RESULT AND DISCUSSION}

\subsection{Results without MPPT}

Modified (POSLC) that shown in Figure 7 has been simulated and analyzed with the parameters shown in Table 1 the simulation results satisfy the theoretical calculation, we choose all inductors with value $0.8 \mathrm{mH}$ and the capacitors with $220 \mu \mathrm{F}$ and the load with $50 \Omega$ and switching frequency $60000 \mathrm{HZ}$, Figure 8(a) shows that the input current of PV panel divided equally between all inductors, that reduce the current pass through one inductor that saves size and protect inductors from high current. Figure 8(b) shows the low level of input pulsating current in the modified circuit can reduce its effect and protect the source.

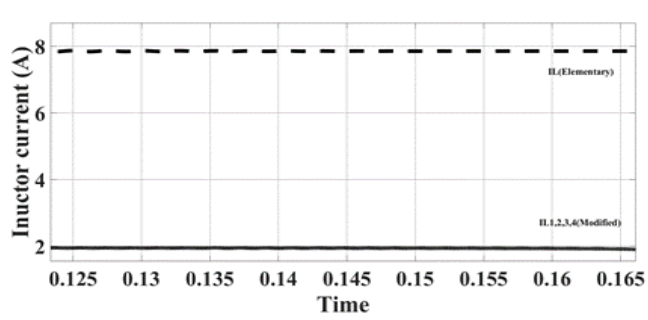

(a)

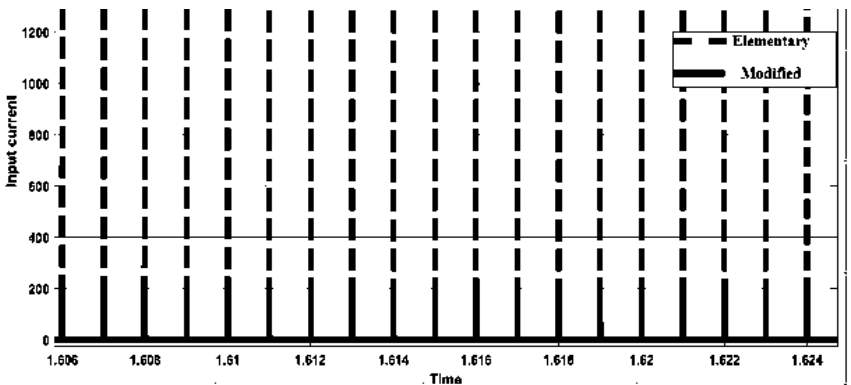

(b)

Figure 8. Modified converter current, (a) inductors currents and (b) input pulsating current

Figure 9(a) shows the difference between output voltage for elementary and modified circuits. Figures 9(b) and 9(c) shows the ripple of modified and elementary converters respectively. The low level of ripple for the modified converter makes the operation more efficient, this is very good for highly sensitive such as medical applications. 


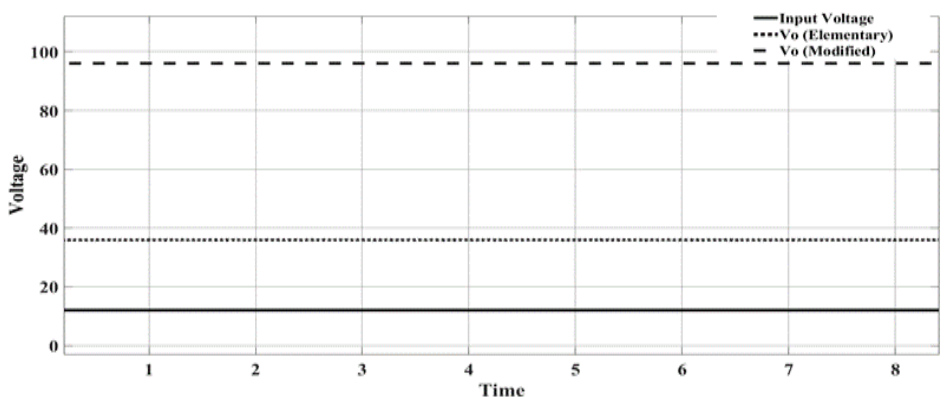

(a)

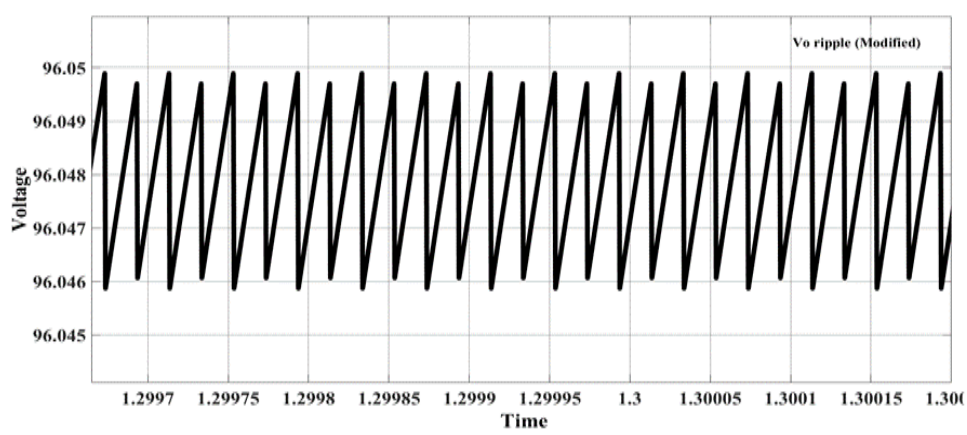

(b)

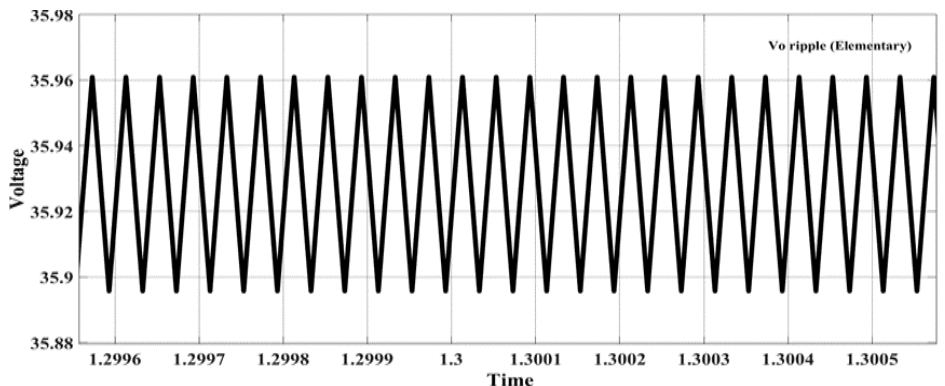

(c)

Figure 9. Output voltage, (a) for both elementary and modified converter, (b) ripple for elementary POSLC, and (c) ripple for modified POSLC

Figure 10 shows the efficiency of the modified is better than a buck-boost converter at a steadystate, while the buck-boost converter instantaneously delivers all the input power to the load. Tables 2 and 3 show a comparison between the modified circuit and the rest of the circuits in the aforementioned research. Table 2 shows the comparison in terms of gain, while Table 3 shows the comprehensive comparison.

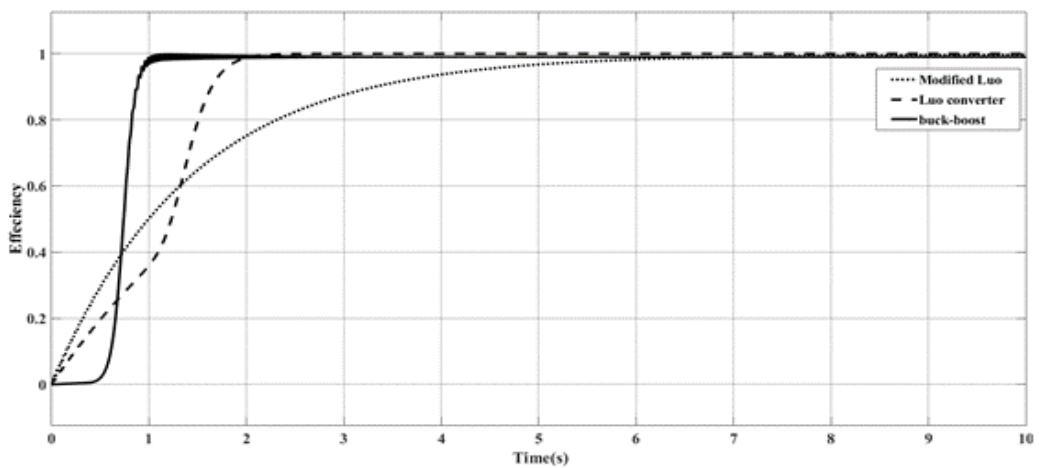

Figure 10. The efficiency of modified converter in compare with traditional Luo and buck-boost converter 
Table 2. The gain formula and the gain factor for $\mathrm{D}=0.2,0.5,0.7$

\begin{tabular}{ccccc}
\hline Topology & Gain formula & Gain at $\mathrm{D}=0.2$ & Gain at $\mathrm{D}=0.5$ & Gain at $\mathrm{D}=0.7$ \\
\hline POSLC & $G=\frac{2-D}{1-D}$ & 2.25 & 3 & 4.333 \\
Modification in [11] & $G=\frac{2}{1-D}$ & 2.5 & 4 & 6.666 \\
Modification in [12] & $G=\frac{3-D}{1-D}$ & 3.5 & 5 & 7.666 \\
Modification in [13] & $G=\frac{3-D}{1-D}$ & 3.5 & 5 & 7.666 \\
Proposed converter & $G=\frac{4}{1-D}$ & 5 & 8 & 13.333 \\
\hline
\end{tabular}

Table 3. The comparison between the proposed converter and other modifications on (POSLC)

\begin{tabular}{ccccccc}
\hline Topology & Gain formula & $\begin{array}{c}\text { No. of } \\
\text { capacitors }\end{array}$ & $\begin{array}{c}\text { No. of } \\
\text { inductors }\end{array}$ & No. of diodes & No. of switches & $\begin{array}{c}\text { Equivalent } \\
\text { resistance }\end{array}$ \\
\hline POSLC & $G=\frac{2-D}{1-D}$ & 2 & 1 & 2 & 1 & 5.6 ohm \\
$\begin{array}{c}\text { Modification } \\
\text { in [11] }\end{array}$ & $G=\frac{2}{1-D}$ & 2 & 2 & 3 & 1 & - \\
$\begin{array}{c}\text { Modification } \\
\text { in [12] }\end{array}$ & $G=\frac{3-D}{1-D}$ & 6 & 1 & 6 & 1 & - \\
$\begin{array}{c}\text { Modification } \\
\text { in [13] }\end{array}$ & $G=\frac{3-D}{1-D}$ & 3 & 2 & 4 & 1 & - \\
$\begin{array}{c}\text { Proposed } \\
\text { converter }\end{array}$ & $G=\frac{4}{1-D}$ & 4 & 4 & 9 & 1 & $1.3 \mathrm{ohm}$ \\
\hline
\end{tabular}

\subsection{Results with MPPT}

To interesting with all of the power generated from the PV panel we should control the converter with maximum power point tracker. The P-V characteristic is shown in Figure 2. Figure 7 shows the modified converter implementation in MATLAB/Simulink with MPPT algorithm to control the converter and extract maximum power point. Figure 11 shows the output power of the proposed converter with MPPT and the efficiency is about $94 \%$. We notice that when MPPT controls the circuit the growth in the power extracted is too obvious in simulation. Figure 11 shows the input power of converter from PV panel, and output power of the converter.

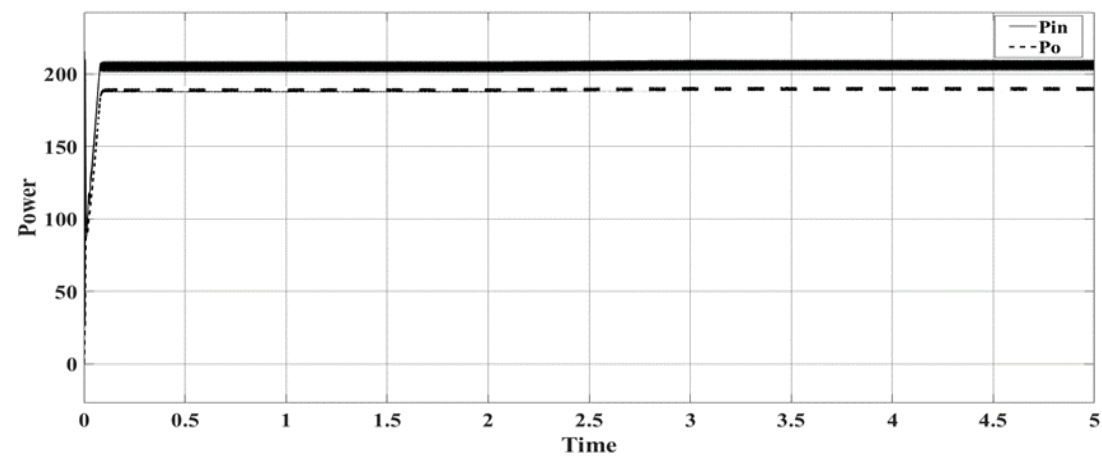

Figure 11. Pin and Po with MPPT controller

\section{CONCLUSION}

The design and model of improved positive output super-lift Luo converter (MPOSLC) are simulated successfully with MATLAB/Simulink and verified the theoretical results. Many switching units can be applied to the DC-DC converter we chose Luo because it was originally a high gain converter. Replacing the inductor with a hybrid unit (S-C-L). The equivalent resistance is reduced and the efficiency is improved, the current intensity in each inductor is reduced to protect them and the use of small-sized inductors and capacitors because the improved converter is reduced capacitor voltage level that makes the size smaller and reduces the cost (the inductor used for low current is small in size and lower in price). The low level of input pulsating current protects the power supply, especially in the non-isolated converter. 
From the boundary conditions, seen the small area of work in DCM and the freer operation in CCM, because the inductor current has not reached zero. This topology can be based on the MPPT of an independent photovoltaic system used in agricultural projects to run pumps used to irrigate crops. We notice that when the converter is controlled by the $\mathrm{P} \& \mathrm{O}$ algorithm the extracting power from $\mathrm{PV}$ increases

\section{REFERENCES}

[1] E. Can, "PWM controlling of a new multi DC-DC converter circuit," Tehnički glasnik, vol. 13, no. 2,pp. 116-122, 2019, doi: $10.31803 /$ tg-20190427093441

[2] E. V. Beulin and J. Pradeep, "Design of Ultra-Lift Luo Converter for Pumping Applications," in International Conference on Power, Energy, Control and Transmission Systems (ICPECTS), Chennai, India, 2018, doi: 10.1109/ICPECTS.2018.8521602.

[3] E. Can, "A new multi-level inverter with reverse connected dual dc to dc converter at simulation," International Journal of Modelling and Simulation, pp. 1-13. 2020, doi: 10.1080/02286203.2020.1824451.

[4] N. Mohan, T. M. Undeland, and W. P. Robbins, "Power Electronics Converters, Applications and Design,” Hoboken New Jersey: John Wiley \& Sons, 2003.

[5] X. Haiping, K. Li, and X. Wen, "Fuel cell power system and high-power DC to DC converter," IEEE Transactions on Power Electronics, vol. 19, no. 5, pp.1250-1255, 2004, doi: 10.1109/TPEL.2004.833440.

[6] L. Zhang, D. Xu, G. Shen, M. Chen, A. Ioinovici, and X. Wu, "A high step-up DC to DC converter under alternating phase shift control for fuel cell power system," IEEE Transactions on Power Electronics, vol. 30, no. 3, pp. 1694-1703, 2014, doi: 10.1109/TPEL.2014.2320290.

[7] T. K. Brekken, H. M. Hapke, C. Stillinger, and J. Prudell, "Machines and drives comparison for low power renewable energy and oscillating applications," IEEE Transactions on Energy Conversion, vol. 25, no. 4, p. 1162-1170, 2010, doi: 10.1109/TEC.2010.2046641

[8] N. Silpa and J. Chitra, "An Improved Luo Converter for High Voltage Applications," International Journal of Emerging Technology and Advanced Engineering, vol. 4, no. 5, pp. 262-267, 2014, doi: 10.1109/CPE.2018.8372547.

[9] F. L. Luo and H. Ye, "Super-lift Boost Converter," IET Power Electron, vol. 7, no. 7, pp. 1655-1664, 2014, doi: 10.1049/ietpel.2012.0531

[10] E. Can. "The design and experimentation of the new cascaded DC-DC boost converter for renewable energy," International Journal of Electronics, vol. 106, no. 9, pp. 1374-1393, 2019, doi: 10.1080/00207217.2019.1591529.

[11] E. Can and H. H. Sayan, "Different mathematical model for the chopper circuit," Tehnički glasnik, vol. 10, no. 1-2, pp. 13-15, 2016, doi: TG-201600117184246.

[12] S. A. Nath and J. Pradeep, "PV Based Design of Improved Positive Output Super-Lift Luo Converter," in Second International Conference on Science Technology Engineering and Management (ICONSTEM), Chennai, India, 2016, doi: 10.1109/ICONSTEM.2016.7560965.

[13] M. P. Chand and G. Ramesh, "Design of new positive output super-lift Luo converter for solar input in comparison with different DC- DC converter," International Research Journal of Engineering and Technology (IRJET), vol. 3, no. 9, pp. 1589-1594, 2016, doi: 10.5370/JEET.2018.13.5.1886.

[14] A. T. Mohammed and N. K. Alshamaa, "Design and Implementation of a Modified Luo Converter with Higher-Voltage Ratio Gain," 3rd International Conference on Sustainable Engineering Techniques (ICSET), Munich, Germany, 2020, doi: 10.1088/1757-899X/881/1/012124.

[15] S. Mohammed, "Modeling and Simulation of Photovoltaic Module using MATLAB/Simulink," International Journal of Chemical and Environmental Engineering, vol. 2, no. 5, pp. 81-90, 2011, doi: 10.1.1.679.7529\&rep=rep1\&type=pdf.

[16] B. Axelrod, Y. Berkovich, and A. Ioinovici, "Switched-capacitor/switched-inductor structures for getting transformerless hybrid DC-DC PWM converters," Transactions on Circuits and Systems I: Regular Papers, vol. 55, no. 2, p. 687-696, 2008, doi: 10.1109/TCSI.2008.916403.

[17] B. Axelrod, Y. Berkovich, and A. Ioinovici, "Transformerless DC-DC converters with a very high DC line-to-load voltage ratio," IEEE International Symposium on Circuits and Systems, Bangkok, 2003, doi: 10.1109/ISCAS.2003.1205049.

[18] K. Li, Y. Hu, and A. Ioinovici, "Generation of the large DC gain step-up non-isolated converters in conjunction with renewable energy sources starting from a pro-posed geometric structure," IEEE transactions on power electronics, vol. 32, no. 7, pp. 53235340, 2016, doi: 10.1109/TPEL.2016.2609501.

[19] R. Kumar, B. Sahu, C. Shiva, and B. Rajender "A control topology for frequency regulation capability in a grid integrated PV system," Archives of Electrical Engineering, vol. 69, no. 2, pp. 389-401, 2020, doi: 10.24425/aee.2020.133033.

[20] G. R. Krishnal and Y. Y. Pundlik, “Analysis of stand-alone photo-voltaic system with boost converter," International Journal of Advanced Technology in Engineering And Science, vol. 4, no. 9, pp. 573-583, 2016.

[21] H. Sharma, N. Pal, and P. K. Sadhu, "Modeling and Simulation of Off-Grid Power Generation System Using Photovoltaic," TELKOMNIKA Indonesian Journal of Electrical Engineering, vol. 13, no. 3, pp. 418-424, 2015, doi: 10.11591/telkomnika.v13i3.7061.

[22] S. S. Mohammed and D. Devaraj, "Simulation and analysis of stand-alone photovoltaic system with boost converter using MATLAB/Simulink," International Conference on Circuits, Power and Computing Technologies (ICCPCT), Nagercoil, India, 2014, doi: 10.1109/ICCPCT.2014.7054991.

[23] R. A. Messenger and A. Abtahi, "Photovoltaic Systems Engineering," Boca Raton, Florida: CRC Press, 2000.

[24] W. De Soto, S. A. Klein, and W. A. Beckman, "Improvement and validation of a model for photovoltaic array performance," Solar Energy, vol. 80, no. 1, pp. 78-88, 2006, doi: 10.1016/j.solener.2005.06.010.

[25] Y. Jiang, J. A. A. Qahouq, and I. Batarseh, "Improved solar PV cell Matlab simulation model and comparison," IEEE International Symposium on Circuits and Systems (ISCAS), pp. 2770-2773, 2010, doi: 10.1109/ISCAS.2010.5537014.

[26] G. Walker, "Evaluating MPPT converter topologies using a Matlab PV model," Journal of Electrical \& Electronics Engineering, Australia, vol. 21, no. 1, pp. 49-55, 2001.

[27] S. Muthukaruppasamy, A. Abudhahir, A. G. Saravanan, J. Gnanavadivel, and P. Duraipandy, "Design and implementation of PIC/FLC plus SMC for positive output elementary super lift luo converter working in discontinuous conduction mode," Journal of Electrical Engineering and Technology, vol. 13, no. 5, pp. 1886-1900, 2018, doi: 10.5370/JEET.2018.13.5.1886.

[28] F. L. Luo and H. Ye, "Essential DC/DC Converters," Boca Raton, Florida: CRC Press, 2018, doi: 10.1201/9781420037104.

[29] H. K. Khalil, S. S. Hreshee, and H. J. Motlak, "Design and Implementation of Photovoltaic System Based on Super-Lift LUO Converter," In Journal of Physics: Conference Series, vol. 1530, no. 1, p. 012013, 2020, doi: 10.1088/1742-6596/1530/1/012013. 
[30] R. Femi, T. S. R. Raja, and R. Shenbagalakshmi, “A positive output-super lift Luo converter fed brushless DC motor drive using alternative energy sources," International Transactions on Electrical Energy Systems, vol. 31, no. 2, p. 12740, 2021, doi: $10.1002 / 2050-7038.12740$

[31] H. J. Motlak and A. S. Rahi, "Performance comparison of different control strategies for the regulation of DC-DC negative output super-lift luo-converter," International Journal of Electrical \& Computer Engineering, 2088-8708, vol. 10, no. 6, pp. 5785-5792, 2020, doi: 10.11591/ijece.v10i6.pp5785-5792.

\section{BIOGRAPHIES OF AUTHORS}

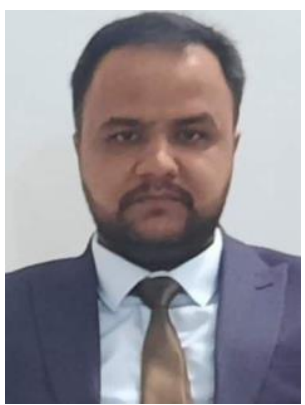

Hussein Abdul-Khuder Hussein (D) Bd SC P received the B.Sc.in Electrical Engineering from the University of Babylon in 2015, interested in industrial engineering work and worked in many engineering factories and now on the way to finish his master's degree in industrial electronics. He can be contacted at email: hussein.radi@student.uobabylon.edu.iq

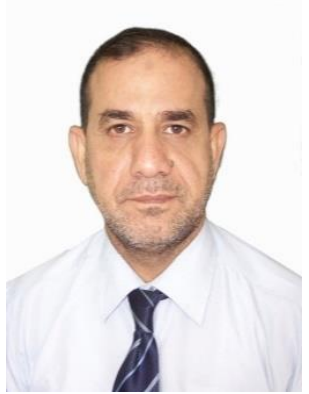

Hassan Jassim Motlak (D) 8d SC P He was born in baghdad on 1966. He received BSc. in Electrical Engineering from university of technology on 1991. He got MSc. in solid state electronics from university of technology on 2001. He got Ph.D. in Electronics and Communication Engineering on 2009 From JMI, new delhi, India. His interested field in design of analog signal proceesing devices. He can be contacted at email: hssn_jasim@yahoo.com. 